Iurii I. Kaliukh ${ }^{1}$, D. S., Professor, Deputy Head of Department ORCID: 0000-0001-7240-4934 e-mail: kalyukh2002@gmail.com

Oleksij G. Lebid ${ }^{2}$, Ph. D., Senior researcher, Acting Deputy Director for Science ORCID:0000-0002-4003-8068 e-mail: o.g.lebid@gmail.com

Volodimyr A. Dunin ${ }^{1}$, Research Associate ORCID: 0000-0002-0370-0825 e-mail: kalyukh2002@gmail.com

Nugzar Margvelashvili ${ }^{3}$, Dr., Ph.D., Sediment modeller e-mail:nugzar.margvelashvili@csiro.au

Yaroslav O. Berchun ${ }^{2}$, Postgraduate of Department of natural resources ORCID: 0000-0002-9373-2870 e-mail: berchun93@gmail.com

Sergiy M. Samoilenko ${ }^{1}$, Senior engineer

ORCID: 0000-0001-9416-4919 e-mail: kalyukh2002@gmail.com

${ }^{1}$ State Enterprise "State Research Institute of Building Constructions", Kyiv, Ukraine ${ }^{2}$ Institute of Telecommunication and Global Information Space of NASU, Kyiv, Ukraine ${ }^{3}$ CSIRO Ocean and Atmosphere, GPO Box 1538, Hobart, Tasmania 7001, Australia

\title{
VIBRODINAMIC MONITORING OF PILE FOUNDATION ENGINEERING ON LANDSLIDE HAZARDOUS SITE IN DENSE URBAN DEVELOPMENT CONDITIONS
}

\begin{abstract}
An example of the application of modern regulatory requirements for the scientific and technical support of construction and monitoring of building structures for the safe arrangement of the pile foundation on a landslide hazardous building site in conditions of dense urban development in Kyiv during the installation of a $\varnothing 820 \mathrm{~mm}$ bored pile according to the plan of the pile field has been considered. Experimentally registered levels of vibration acceleration on the foundation wall of the building in the vertical and horizontal directions do not exceed $0.015 \mathrm{~m} / \mathrm{s}^{2}$, which is significantly lower than the minimum permissible values of vibration acceleration for the foundations of buildings with brick bearing walls $0,15 \mathrm{~m} / \mathrm{s}^{2}$. The research also evaluated the presence of visible damage to the building in the available places and their possible development before and after piles placement. The condition of the plaster screed on a vertical crack in the wall of the house on the 8th floor, which was installed before the start of construction work, after pile foundation installation has not changed - it remained undamaged. Key words: safety; monitoring; pile; technical condition; sensor; vibroacceleration.
\end{abstract}




\section{Introduction}

The general condition of the construction sites in Ukraine does not ensure safe living conditions for citizens and society due to the increased risk of emergencies [1]. The increase in the buildings and constructions height, break with symmetric forms, constant increase in the technogenic load on the site during construction in conditions of dense urban development enhance the likelihood of disasters conditions. First of all, it regards Kyiv where there are numerous examples of such violations:

1. In the center of Kyiv there have been another construction scandal regarding construction of "Elegant" residential development in dense urban development conditions on 118, Zhilyanskaya street [2]. At the beginning of construction process the neighboring five-storey house cracked during the pile driving, the tenants had to be resettled. As a result, an old five-story mansion and a one-storey building next to it on 120-V Zhilianskaya street was broken down and a huge trench was dug on this site. Residents of nearby houses are afraid that the walls of their houses will collapse - the cracks have already appeared on the upper floors [3].

2. Residents of houses number 3, 5, 5a, 7 on Lesya Ukrainka bvld. and three more houses along Mechnikov Street were united by one problem - the construction in their yard. Houses are built on a landslide slope. Delicate balance can be disrupted by any intervention of construction equipment. Houses on Lesya Ukrainka bvld. will simply slide down to Mechnikov Street [4].

3. On 7, Marjanenko lane crack opening in the house walls coincides with the beginning of excavation for a residential complex on 9 and 11 Mechnikova street. The state of the house was affected immediately by two construction sites - 9a and 11 Mechnikov street and 12a Klovskiy uzviz street as well

The above examples are just the tip of the iceberg of constantly increasing number of ground displacements and catastrophes across Ukraine both in terms of their number and in terms of economic losses scale. There is an acute need for monitoring and scientific and technical support for new constructions taking into account the fulfillment of the requirements of new regulatory documents for soil accidents prevention in future [5].

Over the past 10 years State Enterprise "State Research Institute of Building Constructions" gave much attention to both the regulatory and methodological support and to construction monitoring systems implementation. During this time, a number of regulatory documents considering building structures monitoring issues have been developed:

1. State Construction Standard DBN B.1.2-5: 2007 "The scientific and technical support of construction sites" [6].

2. DBN B.1.2-12-2008 "Construction in conditions of dense urban development. Safety requirements" [7].

3. DBN B.1.2-14-2009 "General principles of reliability and buildings, structures and foundations structural safety ensuring" [8].

All of the above documents were a basis for new final document National Standards of Ukraine DSTU-B B.1.2-17: 2016 "Guidance on scientific and technical monitoring of buildings and constructions" [9], which was developed under scientific supervision of prof. Yu.I. Kaliukh as well as complex of standards for buildings and constructions technical diagnostics systems [10]. Construction standards [9] include all the main methodological instructions and developments on 
the scientific and methodological basis, design and experimental development of construction monitoring systems [6-8, 10-11] that were put into effect on 01.04.2017. Guidance [9] was developed in harmonic accordance with international building standards fib [12]. In [9], as in the document fib [12], the classification of construction monitoring systems is the same (see Figure 1 [12]).

Theoretical and methodological issues of the design and organization of monitoring research are analyzed in the works of modern foreign scientists Sassa K., Casagli N., Catani F., Lu P., Mikoš M., Željko A. and others [13-18]. Among the Ukrainian scientists, one should note the researches by associate member of NAS of Ukraine, prof. O. Trofimchuk and prof. I. Kaliukh on theoretical and methodological background of monitoring systems concept, their design and experimental development in practice in construction and geotechnics [19-23], as well as studies in this direction of their students: Kaliukh T. [24], Polevets'kyi V. [25], Klymenkov O. [26], Khavkin K. [27], Berchun Ya. [28], et al.

\section{Main points}

Let's consider an example of modern regulatory requirements application for scientific and technical support for building structures construction and monitoring [6-11] for safe arrangement of the pile foundation on a landslide hazardous construction site in conditions of dense urban development at the address 14, Pimonenka street in Kyiv during the installation of a bored pile № $87 \varnothing 820 \mathrm{~mm}$ in accordance with the pile field plan. The work area with a well for the bored pile is at a distance of 18-20 m from the nine-storey residential brick building. The area of the construction site is below the level of adjacent to the building area, on the boundary of which there is a retaining wall made of concrete blocks in height $\approx 5 \mathrm{~m}$. The mutual location of the building, the retaining wall and the construction site is presented in Fig. 1

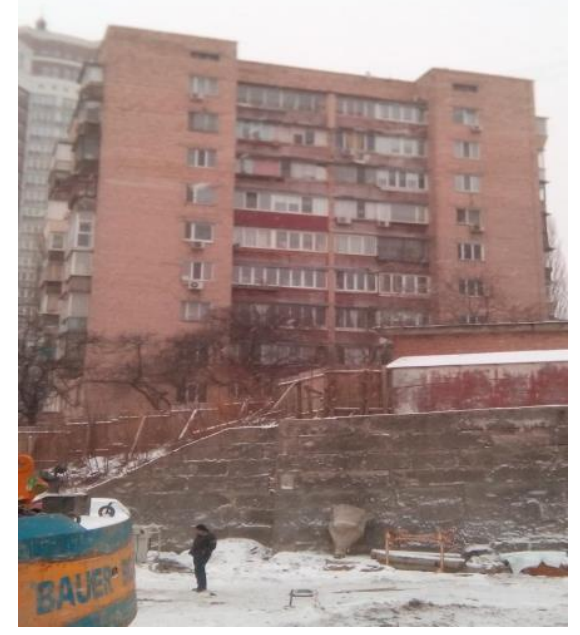

Fig. 1 - Investigated building and retaining wall view

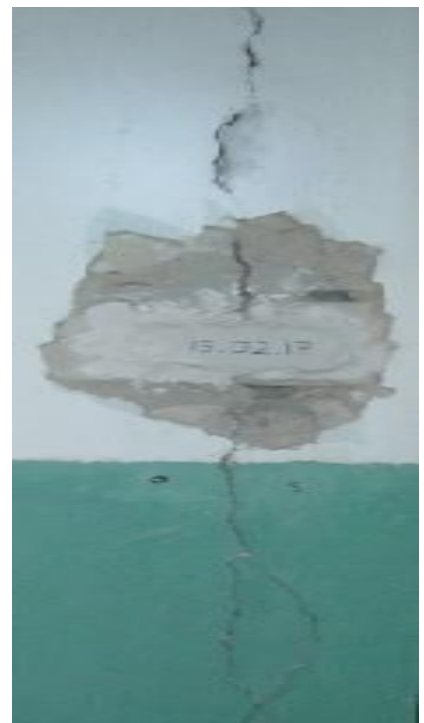

Fig. 2 - Chalky screed state after pile installation 
According to the present DBN [6-11] the inspection of technical condition of the building structures of the nine-storey building was performed in advance, prior to conducting drilling works, (Fig. 1). During the study of the technical condition of building constructions, the presence of visible damage in the places available for this site and their possible development before the works beginning, during and after the installation of the piles were assessed. The monitoring of the impact on building of drilling operations was monitored not only instrumentally, but also visually, by periodic observations during the arrangement of the bored pile № $87 \varnothing 820 \mathrm{~mm}$ taking into account the integrity of the chalky screed on a vertical crack in the bearing brick wall of the house on the 8th floor. The screed was installed in advance, prior to drilling operations beginning (see Fig. 2).

Well drilling was performed by the BAUER 40 BG drilling rig (Fig. 3). In the photo (Fig. 4) there is a view of the investigated building, including the retaining wall on the side of the construction site. During the research period, one drilling rig BAUER 40 BG (Fig. 3) worked on the site.

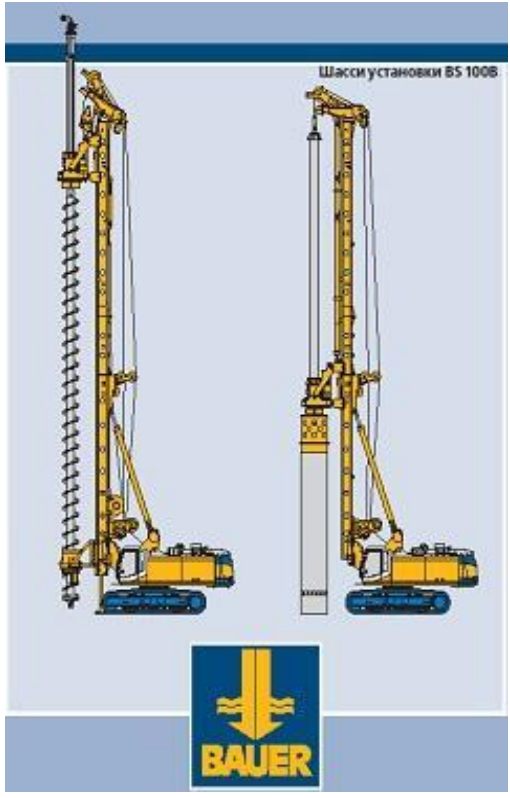

Fig. 3 - Rotary drilling rig BG 40

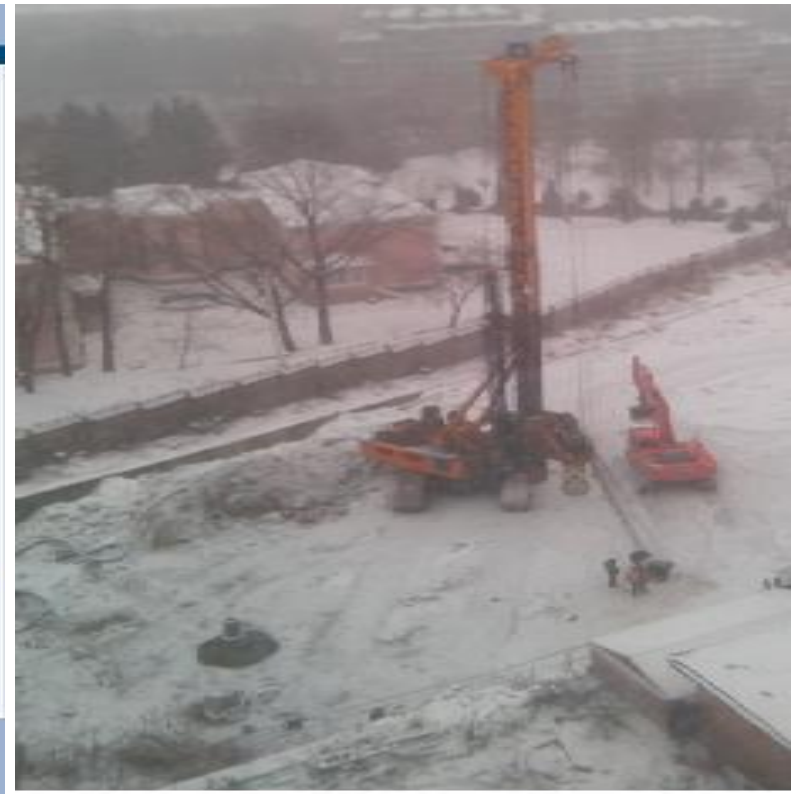

Fig. 4 - Construction site location near the building toe 14, Pimonenko street (view from the flat on the $9^{\text {th }}$ floor)

The vibration sensors were located on the foundation part of the building (3 vibration sensors), fixed oriented towards $\mathrm{X}, \mathrm{Z}$ and $\mathrm{Y}$ directions (Fig. 5); two vibration sensors that were located on the floor of the 9 th floor of the house were oriented towards X, Z or Y, Z directions (Fig. 6). The change in the orientation of the vibration sensors for the measurement of vibration acceleration was conducted in concert with the moment of their registration. 


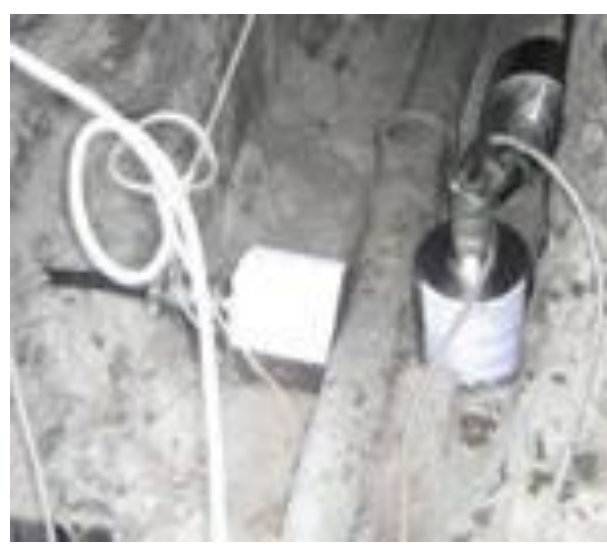

Fig. 5 - Vibration sensors № 1, № 2, № 3 for foundation oscillations registration towards $\mathrm{X}, \mathrm{Z}$ and $\mathrm{Y}$ directions

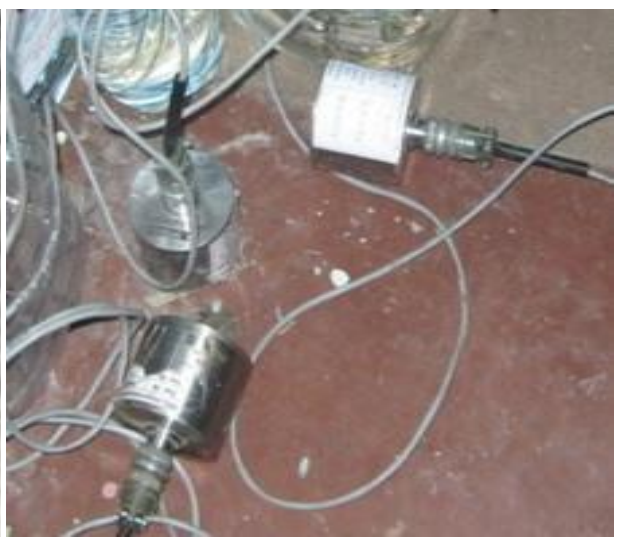

Fig. 6 - Vibration sensors № 4 and № 5 for registration of oscillations of the top $9^{\text {th }}$ floor of the building towards $\mathrm{X}, \mathrm{Z}$ or $\mathrm{Y}, \mathrm{Z}$ directions

\section{Results}

With the help of "Seismic monitoring" software [29] the initial experimental results were processed, that are represented in the table.

Table - The values of vibration acceleration (typical and peak) of the building foundation part (sensors № 1, № 2 and № 3) and the upper 9th floor of the building (sensors № 4 and № 5)

\begin{tabular}{|c|c|c|c|c|}
\hline № & $\begin{array}{l}\text { Monitoring } \\
\text { time }\end{array}$ & Grade, soil & $\begin{array}{c}\text { Max values of vibration } \\
\text { accelerations }\end{array}$ & $\begin{array}{l}\text { Drilling } \\
\text { practice }\end{array}$ \\
\hline 1 & 2 & 3 & 4 & 5 \\
\hline \multirow[t]{5}{*}{1} & \multirow[t]{5}{*}{10.44} & $0 \mathrm{~m}$; Clay & № $1-0.0005,0,002-0.004(\mathrm{X})$ & \multirow{5}{*}{$\begin{array}{l}\text { Silence regime } \\
\text { record }\end{array}$} \\
\hline & & & № $2-0.0005,0,002-0.004(\mathrm{Z})$ & \\
\hline & & & № $3-0.0002,0,002-0.004(\mathrm{Y})$ & \\
\hline & & & № $4-0.0001,0,002-0.003(\mathrm{X})$ & \\
\hline & & & № 5 - $0.0005,0,002-0.004(\mathrm{Z})$ & \\
\hline \multirow[t]{9}{*}{2} & \multirow[t]{9}{*}{10.59} & $0 \mathrm{~m}$; Clay & № $1-0,002-0,004 \quad$ (X) & \multirow{9}{*}{$\begin{array}{l}\text { Drilling start } \\
\text { Well drilling }\end{array}$} \\
\hline & & & № $2-0,001-0,005$ & \\
\hline & & & № $3-0,001-0,002$ & \\
\hline & & & № $4-0,001-0,005$ & \\
\hline & & & № $5-0,001-0,002$ & \\
\hline & & & № $2-0,001-0,003$ & \\
\hline & & & № $3-0,001-0,002$ & \\
\hline & & & № 4 - 0,001-0,002 & \\
\hline & & & № $5-0,0005-0,001$ & \\
\hline \multirow[t]{5}{*}{3} & \multirow[t]{5}{*}{$11: 18$} & 4-5 m; Clay & № $1-0,001-0,003$ & \multirow[t]{5}{*}{ Well drilling } \\
\hline & & & № $2-0,001-0,003$ & \\
\hline & & & № 3 - 0,001-0,002 & \\
\hline & & & № 4 - 0,001-0,002 & \\
\hline & & & № $5-0,0005$ & \\
\hline
\end{tabular}


Table continuation

\begin{tabular}{|c|c|c|c|c|c|}
\hline 1 & 2 & 3 & 4 & & 5 \\
\hline \multirow[t]{5}{*}{4} & \multirow[t]{5}{*}{$11: 20$} & 6-7 m; Clay & № $1-0,001-0,003$ & (X) & \multirow[t]{5}{*}{ Well drilling } \\
\hline & & & № 2 - 0,001-0,006 & $(\mathrm{Z})$ & \\
\hline & & & № 3 - 0,001-0,002 & $(\mathrm{Y})$ & \\
\hline & & & № $4-0,002-0,0025$ & $(\mathrm{X})$ & \\
\hline & & & № $5-0,0005-0.001$ & (Z) & \\
\hline \multirow[t]{5}{*}{5} & \multirow[t]{5}{*}{$11: 22$} & $8 \mathrm{~m}$; Clay & № 1 - 0,001-0,002 & $(\mathrm{X})$ & \multirow{5}{*}{$\begin{array}{l}\text { Microseismic } \\
\text { background. } \\
\text { Tube timbering } \\
\text { lengthening }\end{array}$} \\
\hline & & & № 2 - 0,001-0,003 & (Z) & \\
\hline & & & № 3 - 0,001-0,002 & $(\mathrm{Y})$ & \\
\hline & & & № $4-0,001-0,002$ & (X) & \\
\hline & & & № $5-0,0005-0,001$ & $(\mathrm{Z})$ & \\
\hline \multirow[t]{5}{*}{6} & \multirow[t]{5}{*}{$11: 28$} & $8 \mathrm{~m}$; Clay & № $1-0,002-0,001$ & $(\mathrm{X})$ & \multirow{5}{*}{$\begin{array}{c}\text { Motion of } \\
\text { a drilling rig with } \\
\text { tube timbering }\end{array}$} \\
\hline & & & № $2-0,001-0.0035$ & $(\mathrm{Z})$ & \\
\hline & & & № $3-0,001-0,002$ & $(\mathrm{Y})$ & \\
\hline & & & № $4-0,0015-0,001$ & $(\mathrm{X})$ & \\
\hline & & & № $5-0,0005$ & $(\mathrm{Z})$ & \\
\hline \multirow[t]{5}{*}{7} & \multirow[t]{5}{*}{$11: 40$} & 9-10 m, Clay & № $1-0,0015-0,004$ & $(\mathrm{X})$ & \multirow{5}{*}{$\begin{array}{l}\text { Tube timbering } \\
\text { spudding with } \\
\text { further drilling }\end{array}$} \\
\hline & & & № $2-0,001-0,005$ & $(\mathrm{Z})$ & \\
\hline & & & № $3-0,002-0,003$ & $(\mathrm{Y})$ & \\
\hline & & & № $4-0,001-0,005$ & $(\mathrm{X})$ & \\
\hline & & & № $5-0,002-0,0005$ & $(\mathrm{Z})$ & \\
\hline \multirow[t]{5}{*}{8} & \multirow[t]{5}{*}{$11: 56$} & $\begin{array}{c}14-16 \mathrm{~m}, \\
\text { Clayed sand }\end{array}$ & № 1 - 0,001-0,002; 0,006 & $(\mathrm{X})$ & \multirow[t]{5}{*}{ Well drilling } \\
\hline & & & № 2 - 0,001-0,002; 0,006 & $(\mathrm{Z})$ & \\
\hline & & & № $3-0,001-0,002$ & $(\mathrm{Y})$ & \\
\hline & & & № 4 - 0,001-0,0015 & $(\mathrm{X})$ & \\
\hline & & & № $5-0,0003$ & (Z) & \\
\hline \multirow[t]{5}{*}{9} & \multirow[t]{5}{*}{$12: 05$} & $\begin{array}{c}16 \mathrm{~m}, \\
\text { Clayed sand }\end{array}$ & № 1 - 0,001-0,0015 & $(\mathrm{X})$ & \multirow{5}{*}{$\begin{array}{c}\text { Microseismic } \\
\text { background. } \\
\text { Tube timbering } \\
\text { lengthening }\end{array}$} \\
\hline & & & № 2 - 0,0005; 0,002 & $(\mathrm{Z})$ & \\
\hline & & & № $3-0,0005$ & $(\mathrm{Y})$ & \\
\hline & & & № 4 - 0,0005; 0,003 & $(\mathrm{X})$ & \\
\hline & & & № $5-0,0005$ & $(\mathrm{Y})$ & \\
\hline \multirow[t]{5}{*}{10} & \multirow[t]{5}{*}{12.50} & $\begin{array}{c}17-18 \mathrm{~m}, \\
\text { Clayed sand }\end{array}$ & № 1 - 0,006-0,008 & $(\mathrm{X})$ & \multirow[t]{5}{*}{ Well drilling } \\
\hline & & & № 2 - 0,004; $0,001-0,003$ & $(\mathrm{Z})$ & \\
\hline & & & № $3-0,001-0,003 ; 0,015$ & $(\mathrm{Y})$ & \\
\hline & & & № $4-0,0035$ & (X) & \\
\hline & & & № 5 - 0,0005; 0,0015 & $(\mathrm{Z})$ & \\
\hline \multirow[t]{5}{*}{11} & \multirow[t]{5}{*}{$12: 54$} & $\begin{array}{l}18-19 \mathrm{~m}, \\
\text { Clayed sand }\end{array}$ & № $1-0,006$ & $(\mathrm{X})$ & Well drilling \\
\hline & & & № 2 - 0,001-0,003; 0,004 & $(\mathrm{Z})$ & \\
\hline & & & № $3-0,0025-0,0015 ; 0,005$ & $(\mathrm{Y})$ & \\
\hline & & & № 4 - 0,002-0,004 & $(\mathrm{X})$ & \\
\hline & & & № 5 - 0,0005; 0.003 & $(\mathrm{Z})$ & \\
\hline 12 & $12: 56$ & $\begin{array}{c}19-20 \mathrm{~m}, \\
\text { Clayed sand }\end{array}$ & № 1 - 0,006 & $(\mathrm{X})$ & Well drilling \\
\hline & & & № $2-0,002-0,005$ & $(\mathrm{Z})$ & \\
\hline & & & № $3-0,0025-0,003 ; 0.006$ & $(\mathrm{Y})$ & \\
\hline & & & № $4-0,0025$ & $(\mathrm{X})$ & \\
\hline & & & № 5 - 0,0025 & (Z) & \\
\hline
\end{tabular}


Table continuation

\begin{tabular}{|c|c|c|c|c|c|}
\hline 1 & 2 & 3 & 4 & & 5 \\
\hline \multirow[t]{5}{*}{13} & \multirow[t]{5}{*}{$13: 22$} & $\begin{array}{l}22 \mathrm{~m}, \text { Watered } \\
\text { clayed sand }\end{array}$ & № 1 - 0,001-0,003 & $(\mathrm{X})$ & \multirow[t]{5}{*}{ Well drilling } \\
\hline & & & № $2-0,001-0,006$ & $(\mathrm{Z})$ & \\
\hline & & & № $3-0,001-0,002$ & $(\mathrm{Y})$ & \\
\hline & & & № $4-0,001-0,0025$ & $(\mathrm{X})$ & \\
\hline & & & № $5-0,0005-0,003$ & (Z) & \\
\hline \multirow[t]{5}{*}{14} & \multirow[t]{5}{*}{$13: 36$} & $\begin{array}{l}24-25 \mathrm{~m}, \text { Watered } \\
\text { clayed sand, Red clay }\end{array}$ & № 1 - 0,001-0,0015 & $(\mathrm{X})$ & \multirow[t]{5}{*}{ Well drilling } \\
\hline & & & №2 - 0,0005; 0,002 & $(\mathrm{Z})$ & \\
\hline & & & № $3-0.0008$ & (Y) & \\
\hline & & & № 4 - 0,0005-0,002 & $(\mathrm{X})$ & \\
\hline & & & № 5 - 0,004; 0,0005 & $(\mathrm{Z})$ & \\
\hline \multirow[t]{5}{*}{15} & \multirow[t]{5}{*}{$14: 04$} & 28-30 m, Hard marl & № 1 - 0,001-0,002 & $(\mathrm{X})$ & \multirow[t]{5}{*}{ Well drilling } \\
\hline & & & № $2-0,001-0,002$ & $(\mathrm{Z})$ & \\
\hline & & & № 3 - 0,001-0,002 & $(\mathrm{Y})$ & \\
\hline & & & № 4 - 0,0025-0,001 & $(\mathrm{X})$ & \\
\hline & & & № $5-0,0003$ & $(\mathrm{Z})$ & \\
\hline \multirow[t]{5}{*}{16} & \multirow[t]{5}{*}{$14: 32$} & $\begin{array}{c}\text { 32-33 m, Waterlogged } \\
\text { marl, Hard clay }\end{array}$ & № 1 - 0,001-0,004 & $(\mathrm{X})$ & \multirow[t]{5}{*}{ Well drilling } \\
\hline & & & № $2-0,0005-0,003$ & $(\mathrm{Z})$ & \\
\hline & & & № 3 - 0,001-0,002 & $(\mathrm{Y})$ & \\
\hline & & & № $4-0,0025-0,001$ & $(\mathrm{X})$ & \\
\hline & & & № $5-0,0005$ & (Z) & \\
\hline \multirow[t]{5}{*}{17} & \multirow[t]{5}{*}{$14: 43$} & $\begin{array}{c}\text { 35-36 m, Compacted } \\
\text { marl }\end{array}$ & $0,0008-0,0015$ & $(\mathrm{X})$ & \multirow[t]{5}{*}{ Well drilling } \\
\hline & & & $0,001-0,002$ & $(\mathrm{Z})$ & \\
\hline & & & 0,001 & $(\mathrm{Y})$ & \\
\hline & & & 0,$001 ; 0,002$ & $(\mathrm{X})$ & \\
\hline & & & 0,0005 & $(\mathrm{Z})$ & \\
\hline \multirow[t]{5}{*}{18} & \multirow[t]{5}{*}{$15: 13$} & 37-38 m, Marl & $0,001-0,002 ; 0,004$ & $(\mathrm{X})$ & \multirow[t]{5}{*}{ Well drilling } \\
\hline & & & $0,001-0,0015 ; \quad 0,005$ & $(\mathrm{Z})$ & \\
\hline & & & $0,001-0,0015 ; \quad 0,003$ & $(\mathrm{Y})$ & \\
\hline & & & 0,$001 ; 0,002$ & $(\mathrm{X})$ & \\
\hline & & & 0,0035 & $(\mathrm{Z})$ & \\
\hline \multirow[t]{5}{*}{19} & \multirow[t]{5}{*}{$15: 26$} & 38-39,5 m, Marl & $0,001-0,002$ & $(\mathrm{X})$ & \multirow[t]{5}{*}{ Well drilling } \\
\hline & & & $0,001-0,002$ & $(\mathrm{Z})$ & \\
\hline & & & $0,001-0,0015$ & $(\mathrm{Y})$ & \\
\hline & & & 0,$001 ; 0,002$ & $(\mathrm{X})$ & \\
\hline & & & 0,$0025 ; 0,0005$ & $(\mathrm{Z})$ & \\
\hline \multirow[t]{5}{*}{20} & \multirow[t]{5}{*}{17.25} & $39.5-35 \mathrm{~m}$ & № 1 - 0,001-0,002 & $(\mathrm{X})$ & \\
\hline & & & № 2 - 0,001-0,004; 0,006 & $(\mathrm{Z})$ & with concrete at \\
\hline & & & № 3 - 0,001-0,0015 & $(\mathrm{Y})$ & $\begin{array}{l}\text { the point of } \\
395-35 \mathrm{~m}\end{array}$ \\
\hline & & & № $4-0,0015 ; 0,003$ & $(\mathrm{X})$ & \\
\hline & & & № $5-0,0005$ & $(\mathrm{Z})$ & \\
\hline 21 & 17.35 & $39,5 \mathrm{~m}$ & № $1-0,0005-0,001$ & $(\mathrm{X})$ & Lifting of tube \\
\hline & & & № $2-0,0005$ & $(\mathrm{Z})$ & timbering from \\
\hline & & & № 3 - 0,0005-0,0008 & $(\mathrm{Y})$ & the well in $39,5 \mathrm{~m}$ \\
\hline & & & № 4 - 0,0015; 0,0005 & $(\mathrm{X})$ & \\
\hline & & & № $5-0,0005$ & $(\mathrm{Z})$ & \\
\hline
\end{tabular}


Table continuation

\begin{tabular}{|c|c|c|c|c|c|}
\hline 1 & 2 & 3 & 4 & & 5 \\
\hline \multirow[t]{5}{*}{22} & \multirow[t]{5}{*}{17.41} & $31-23 \mathrm{~m}$ & № $1-0,0015-0,001$ & (X) & \multirow{5}{*}{$\begin{array}{l}\text { Well filling } \\
\text { with concrete at } \\
\text { the point of } \\
31-23 \mathrm{~m}\end{array}$} \\
\hline & & & № 2 - 0,0012-0,0003 & (Z) & \\
\hline & & & № $3-0,0015-0,0003$ & $(\mathrm{Y})$ & \\
\hline & & & № 4 - 0,0025-0,0008 & $(\mathrm{X})$ & \\
\hline & & & № 5 - 0,0003 & $(\mathrm{Z})$ & \\
\hline \multirow[t]{5}{*}{23} & \multirow[t]{5}{*}{17.56} & $31,5 \mathrm{~m}$ & № $1-0,001-0,0018$ & $(\mathrm{X})$ & \multirow{5}{*}{$\begin{array}{l}\text { Lifting of tube } \\
\text { timbering from } \\
\text { the well in } 31,5 \mathrm{~m} \\
\text { depth }\end{array}$} \\
\hline & & & № 2 - 0,001-0,0003 & $(\mathrm{Z})$ & \\
\hline & & & № 3 - 0,001-0,0002; 0,006 & $(\mathrm{Y})$ & \\
\hline & & & № 4 - 0,001-0,002 & $(\mathrm{X})$ & \\
\hline & & & № $5-0,0003$ & $(\mathrm{Z})$ & \\
\hline
\end{tabular}

\section{Conclusions}

An example of use of modern regulatory requirements for the scientific and technical support of construction and building structures monitoring [6-11] is considered for safe installation of the pile foundation on a landslide hazardous building site under conditions of dense urban development at the address 14, Pymonenka street in Kiev during the installation of a bored pile № $87 \varnothing 820 \mathrm{~mm}$ in accordance with the plan of the pile field. Continuous monitoring of the piling process was conducted from 10.44 (time of works start) to 17.56 (time of works end). The materials obtained from experiments have shown:

1. The registered vibration acceleration levels on the foundation wall of the building in the vertical and horizontal directions do not exceed $0.015 \mathrm{~m} / \mathrm{s}^{2}$, which is considerably less than the minimum permissible values of vibration acceleration for the foundations of buildings with brick bearing walls $0,15 \mathrm{~m} / \mathrm{s}^{2}$ according to Table 2 in [30].

2 . The registered levels of vibration acceleration at the level of the 9th floor slab of the building in the vertical and horizontal directions do not exceed $0.004 \mathrm{~m} / \mathrm{s}^{2}$, which is significantly lower than the permissible values of vibration acceleration for high-rise buildings of $0.08 \mathrm{~m} / \mathrm{s}^{2}$ in according with paragraph 7.2 [31].

3 . In the studies, the presence of visible damags to the building in the available places and possible development before and after pile installation was also assessed. Their development was evaluated according to a plaster screed on a vertical crack in the wall of the house. The condition of the chalky screed was established prior to the beginning of vibration dynamical tests on $02 / 15 / 2017$ on the vertical crack in the building on the 8th floor, on the date of research on 02/21/2017 and after the installation of the concrete pile and further entire pile foundation has not changed. It remained undamaged. This is shown in the photo (Fig. 2).

4. Based on the above mentioned, it is permissible to carry out work on pile foundation implementation with the observance of the necessary technological procedures during the operation of the BAUER 40 BG drilling rig (see Fig. 3-4).

5. For the control of pile concreting quality, modern theoretical-numerical developments and technical means of the SE "SRIBC" [32-34] can be used.

\section{REFERENCES}

1. Accidents on buildings and structures and their prevention. Proceedings of the Second scientific and technical conference. - K. - 1999.

2. Don't construct any more, but sell. Top-10 illegal housing estates in Kyiv. Available at http://eveningkiev.com/article/33946 
3. Property developers destroy old historical buildings in Kyiv Centre. Available at: https://censor.net.ua/photo_news/254614/v_tsentre_kieva_zastroyischiki_rushat_starinnye_ doma_foto

4. Pechersk. New housing estate on hazardous slope: authority, greed, batts and landslides. Available at: https://censor.net.ua/resonance/166/pechersk_novostroyi_na_opasnom_ sklone_vlast_jadnost_bity_i_opolzni_viktoriya_vladina_dlyatsenzornet

5. Cracked buildings in Kyiv can count just on installation of "indicators". Available at: http://eveningkiev.com/article/36152

6. DBN V.1.2-5:2007 «Scientific and technical support of construction facilities" - K.: Ukrbudarchinform, 2007. - $14 \mathrm{c}$.

7. DBN V.1.2-12-2008 «Construction in dense urban development conditions. Safety requirements» - K.: Ukrbudarchinform, 2007. - $34 \mathrm{p}$.

8. DBN V.1.2-14-2009 «Common principles of buildings, construction structures and foundations reliability and safety provision» - K.: Ukrbudarchinform 007. $-14 \mathrm{p}$.

9. Guidance as for scientific and technical monitoring of buildings and structures: DSTU-N B V.1.2-17:2016 / I. Kaliukh, O. Trofymchuk, Y. Berchun et al. // [In effect since 01 April 2017]. - K. : Minregionbud, 2017. -42 p.

10. DSTU B V.2.6 - 25 - 2003. «Automated systems for technical diagnostics of building structures. General technical requirements»- K.: State Committee for Construction and Architecture of Ukraine, 2003. - 25 c.

11. Buildings and structures. Design of high rise housing estates and public buildings. DBN V.2.2-24:2009. Kyiv. Minenergobud, 2009.

12. Monitoring and safety evaluation of existing concrete structures. State of art report by Task Group 5.1. -International Federation for Structural Concrete (fib), 2003 - 300 p.

13. Sassa K. (2005) Landslides: Risk analysis and sustainable disaster management [Online], http://www.ebook3000.com/Kyoji-Sassa-Landslides-Risk-Analysis-and-Sustainable-DisasterManagement-147509.html.

14. Casagli N., Catani F., Del Ventisette C., Luzi G. (2010) Monitoring, prediction, and early warning using ground-based radar interferometry. Landslides 7(3):291-301

15. Pieraccini M., Casagli N., Luzi G., Tarchi D., Mecatti D., Noferini L., Atzeni C. (2003) Landslide monitoring by ground-based radar interferometry: a field test in Valdarno (Italy). Int J Remote Sens 24(6):1385-1391.

16. Casagli N., Tofani V., Ciampalini A., Raspini F., Lu P., Morelli S. (2018) TXT-tool 2.039-3.1: Satellite Remote Sensing Techniques for Landslides Detection and Mapping. In: Sassa K. et al. (eds) Landslide Dynamics: ISDR-ICL Landslide Interactive Teaching Tools. Springer, Cham. P. 235-254.

17. Hübl J., Mikoš M. (2018) TXT-tool 2.386-1.2: Practice Guidelines on Monitoring and Warning Technology for Debris Flows. In: Sassa K. et al. (eds) Landslide Dynamics: ISDRICL Landslide Interactive Teaching Tools. Springer, Cham

18. Mihalic S, Mihalić A, Željko A, Martin K (2013) TXT-tool 2.385-1.2 A comprehensive landslide monitoring system: The Kostanjek landslide, Croatia [Online], https://scholar.google.fr/citations?view_op=view_citation\&hl=ru\&user=7eoSoYYAAAAJ \&citation_for_view=7eoSoYYAAAAJ:D03iK_w7-QYC

19. Mitigation of landslide hazards in Ukraine under the guidance of ICL: 2009-2016 (IPL 153\&191) / O. Trofymchuk. I. Kaliukh, K. Silchenko, V. Berchun, T. Kaliukh, Y. Berchun // 4th World Landslide Forum, Ljubljana Slovenia EU, 29 May-2 June, 2017. [s.l.: s.n.], 2017. - P. $381-388$.

20. Trofymchuk, O., Kaliukh, I., Berchun V. (2017) Landslide stabilization in building practice: methodology and case study from autonomic Republic of Crimea. 4th World Landslide Forum, Ljubljana Slovenia EU, 29 May - 2 June, 2017. - [s.l.: s.n.], 2017. Workshop on World Landslide Forum. Springer, Cham: 587-595.

21. Modern information and analytical decision making support systems for areas sustainable development provision / [I. Kaliukh, O. Dudarenko, T. Kaliukh et al.] // Scientific and methodological reference guide. Kyiv: Tov. "Znannya", $2000-32$ p. 
22. Kaliukh I., Kadilnikova T. Reference book on development and design of monitoring systems for complex technical systems and construction facilities. - K.: NIISK, 2004. - 46 p. 23. Trofymchuk O., Kaliukh I., Silchenko K., Polevetskiy V., Berchun V., Kalyukh T. (2015) Use Accelerogram of Real Earthquakes in the Evaluation of the Stress-Strain State of Landslide Slopes in Seismically Active Regions of Ukraine. In: Lollino G. et al. (eds) Engineering Geology for Society and Territory - Volume 2. Springer, Cham. - pp. 1343-1346.

24. Kaliukh T. Assessment of stress condition of landslide hazardous slopes in seismic loads conditions: thesis for Technical degree by specialty 05.15.09 - "Geotechnical and mining mechanical engineering". / T. Kaliukh. - K, 2011. - 173 p.

25. Polevetskiy V. Regional features of landslide protect structures and landslide hazardous slopes in Chernivtsi oblast: thesis for Technical degree by specialty 05.23.02 Foundamentals and foundations / V. Polevetskiy - K.: SRIBK, 2010. - 204 p.

26. Klimenkov $\mathrm{O}$. Theoretical and methodological and practical aspects of buildings and landslide hazardous areas monitoring / O. Klymenkov, Y. Berchun // 15 International scientific and practical conference "Modern information technologies of environmental safety management, nature management, emergency actions", Kyiv, Pushcha-Voditsa, 3-6.10.16: thesis. - K .: ITHIP NASU, 2016. - P. 152-154.

27. Khavkin K. Landslide hazard and stress-strain state of landslide protection structures in seismically hazardous regions of Ukraine (for example, Bukovina): thesis for Technical degree by specialty 05.23.02 - "Fundamentals and foundations" / K. Khavkin - K. : SRIBK, 2015. - 188 p.

28. Kaliukh I. Monitoring of the Livadia Palace with changes in the physical and mechanical characteristics of the soils of the central Livadia shear equilibrium system / I. Kalyukh, O. Klymenkov, Y. Berchun // Ecological safety. - 2016. - No. 1 - 2 (21). - P. 69-82.

29. National Technical University of Ukraine "Kyiv Polytechnic Institute". Scientific and technical center "NPP technical equipment diagnostics". Management program. "Seismomonitoring" multichannel measuring system, version 1.0. Operator's Guide. Kiev, 2009.20. DSTU GOST 12.1.012: 2008. Vibrational security. General requirements. M. - 1990. 30. Rate making of structures vibration in the USSR and abroad. Issue 1. M. - 1990.

31. DSTU 12.1.012-2008. SSBT. Vibrational security. - M. - 1990.

32. Experimental and theoretical diagnostics of ferroconcrete piles base on reflection of longitudinal and transverse waves) / G. Farenyuk, I. Kaliukh, E. Farenyuk, T. Kaliukh, Y. Berchun, V. Berchun / International fib symposium "High tech concrete: Where technology and engineering meet!", Maastricht, The Netherlands, 12-14 June, 2017. [s.l. : s.n.], 2017. - P. 1307-1317.

33. Kaliukh I., Senatorov V., Marienkov N., Trofymchuk O., Silchenko K., Kalyukh T. Arrangement of deep foundation pit in restricted conditions of city build-up in landslide territory with considering of seismic loads of 8 points. In: Proceedings XVI ECSMGE, 1317 Sept 2015, Edinburgh, Great Britain, pp. 535-540 (2015).

34. Technoecology: textbook for students of institutes of higher education / V.M. Udod, V.V. Trofimovich, O.S. Voloshkina, O.M. Trofimchuk; KNUBA, ITGIP NANU. - K., 2007 $195 \mathrm{p}$.

Text of the article was accepted by Editorial Team 23.01.2018

Ю.І. Калюх, О.Г. Лебідь, В.А. Дунін, Н. Маргвелашвілі, Я.О. Берчун, С.М. Самойленко ВІБРОДИНАМІЧНИЙ МОНІТОРИНГ УЛАШТУВАННЯ ПАЛЬОВОГО ФУНДАМЕНТУ НА ЗСУВОНЕБЕЗПЕЧНІЙ ДІЛЯНЦІ В УМОВАХ УЩІЛЬНЕНОЇ МІСЬКОЇ ЗАБУДОВИ

Анотація. Розглянуто приклад застосування сучасних нормативних вимог щодо науково-технічного супроводу будівництва та моніторингу будівельних конструкцій для безпечного улаштування пальового фундаменту на зсувонебезпечній будівельній ділянці в умовах ущільненої міської забудови в м. Києві під час влаштування 
буронабивної палі Ø820 мм згідно з планом пальового поля. Експериментально зареєстровані рівні віброприскорень на фундаментній стіні будівлі в вертикальному та горизонтальному напрямках не перевищують 0,015 м/ $\mathrm{c}^{2}$, що значно менше мінімально допустимих значень віброприскорень для фундаментів будівель з цегляними несучими

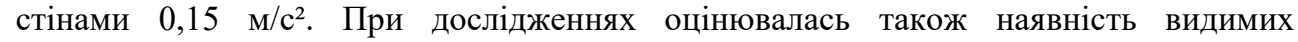
ушкоджень в будівлі в доступних для цього місцях та їх можливий розвиток до і після влаштування палі. Стан гіпсового маяка на вертикальній тріщині в стіні будинку на 8-му поверсі, який був встановлений до початку будівельних робіт, після влаштування пальового фундаменту не змінився - він залишився неушкодженим.

Ключові слова: безпека; моніторинг; паля; технічний стан; датчик; вібродинаміка.

\section{Автори (науковий ступінь, вчене звання, посада):}

\section{Калюх Юрій Іванович}

доктор технічних наук, професор, заступник завідувача відділу ДП «Науково-дослідний інститут будівельних конструкцій»

Адреса робоча: 03037 Україна, вул. Преображенська, 5/2

ORCID: 0000-0001-7240-4934 e-mail: kalyukh2002@gmail.com

\section{Лебідь Олексій Григорович}

кандидат технічних наук, старший науковий співробітник, заступник директора 3 наукової роботи

Інститут телекомунікацій і глобального інформаційного простору НАНУ

Адреса робоча: 03186 Україна, м. Київ, Чоколівський бульвар, 13

ORCID:0000-0002-4003-8068 e-mail: o.g.lebid@gmail.com

\section{Дунін Володимир Андрійович}

науковий співробітник

ДП «Науково-дослідний інститут будівельних конструкцій»

Адреса робоча: 03037 Україна, вул. Преображенська, 5/2

ORCID: 0000-0002-0370-0825 e-mail: kalyukh2002@gmail.com

\section{Маргвелашвілі Нугзар}

кандидат технічних наук, начальник відділу

CSIRO Ocean and Atmosphere

Адреса робоча: GPO Вох 1538, Хобарт, Тасманія 7001, Австралія

e-mail:nugzar.margvelashvili@csiro.auph: +61(03) 62325142

\section{Берчун Ярослав Олександрович}

аспірант відділу природних ресурсів

Інститут телекомунікацій і глобального інформаційного простору НАН України

Адреса робоча: 03186 Україна, м. Київ, Чоколівський бульвар, 13

ORCID: 0000-0002-9373-2870 e-mail: berchun93@gmail.com

\section{Самойленко Сергій Миколайович}

провідний інженер

ДП «Науково-дослідний інститут будівельних конструкцій»

Адреса робоча: 03037 Україна, вул. Преображенська, 5/2

ORCID: 0000-0001-9416-4919 e-mail: kalyukh2002@gmail.com 